\title{
ECCENTRICITY OF CURRENT ANNUAL INCREMENTS IN THE TRUNKS OF SPRUCE (PICEA ABIES (L.) H. KARST) GROWING ALONG THE STREAM CHANNEL IN A SMALL MOUNTAINOUS CATCHMENT IN THE POLISH CARPATHIANS
}

\author{
Ewa Słowik-Opoka*
}

Department of Forest Utilisation, Forest Engineering and Technology,

Faculty of Forestry, University of Agriculture in Krakow, al. 29 listopada 46, 31-425 Krakow

\section{ABSTRACT}

Flooding occurring in mountainous rivers and stream channels, combined with the transport of rock material, cause erosive undercutting of slopes and damage to the exposed root systems of trees growing on banks. The consequence of high-energy events occurring in the stream channel is the generation of mechanical stress in the form of tension inside the tree trunks, resulting in a change in the cambium functioning pattern and deflection of the trunk heartwood. In the present work, the hypothesis that not only rapid landslide phenomena, but also the erosion activity of the stream can cause trees to be tilted from the vertical, which results in the eccentricity of current annual increments of trees growing in the vicinity of the stream channel was adopted. Thanks to this feature of trees, it is also possible to precisely determine the time of occurrence of high-intensity erosion phenomena in the past, as well as to indicate locations along the stream channel that are particularly vulnerable to these processes, which emphasizes the utilitarian aspect of the present work. The objective of this study is to assess the eccentricity of current annual increments in the trunks of spruce trees (Picea abies (L.) H. Karst) growing along the stream in a small forest mountainous catchment. The subject of the study is the width of the growth rings formed by spruces on both sides of the trunk as a form of response to

*凶 ewa.opoka@urk.edu.pl 
the erosive activity of the stream. As a part of the fieldwork, incremental cores were made using the Pressler drill. The annual growth rings of spruce tree trunks were determined using the CooRecorder software, and the obtained results were additionally corrected in the CDendro application. The highest values of the eccentricity index of annual increments in the examined spruces were recorded in the 1960s and 1980s. The causes of stress inside the trunks of the studied trees include both natural erosion processes occurring on the slopes in the catchment area, and high-energy events occurring in the stream channel. Assessment of the eccentricity of annual increments, in combination with geomorphological and hydrological studies, may find its application in the works covering the problems of the dynamics of erosive processes occurring in forest mountainous catchments.

\section{KEYWORDS}

Polish Carpathians $\bullet$ forest catchment $\bullet$ stream $\bullet$ Norway spruce $\bullet$ annual increments - eccentricity index

\section{Introduction}

Mountainous forested areas, characterized by large terrain gradients, are particularly exposed to erosion processes, occurring both on the slopes and in valleys or in the stream channels. From the point of view of the protection of natural resources and of forest management, erosion processes are among many factors that cause stress and affect the proper growth and structure of trees. High-energy geomorphological processes, such as avalanches, landslides, debris flows on slopes or floods in stream channels cause mechanical injuries, followed by the formation of resin canals in conifers (Lundstrom et al. 2008). Trees growing on areas affected by erosion, transport or deposition of material are subjected to mechanical stress (Butler 1987). Their root systems are often bent or exposed. This stress is recorded in the wood of trunks and roots in the form of anatomical changes, including current annual increments, reactive wood formation, or the appearance of resin canals (Schroeder and Butler 1987, Schweingruber 1996).

Under certain climatic conditions, i.e. when there is a rest period during the year, in principle, without exception, the boundaries of rings of current annual increments are visible in trees (Wojciechowski et al. 2013). This phenomenon makes each and every tree rather like a "witness to the history of the place" in which it lives, and thus a witness to the history of processes and changes occurring in the environment and climate changes in the area. All this is because of the deposition of annual increment rings, whose widths vary depending on the tensions occurring within the trunk. These tensions or stress can arise as a result of gravity and strain, or be caused by environmental stimuli (Malik and Wistuba 2012). In the case when the forces acting on the pith are distributed symmetrically along the perimeter of the trunk, the growth of the tree is concentric. When this tree is subjected to stress, e.g. as a consequence of water erosion on the slope, the trunk gradually deviates from the vertical, the cambium pattern changes, and as a result the tree's increment becomes eccentric (Tomczak et al. 2012). 
Dendrogeomorphology is one of the most dynamically developing branches of dendrochronology in the world (Stoffel and Corona 2014). The dendrochronological method, within its applications in the field of geomorphology, uses various tools to study slope stability, sediment accumulation, earthquakes, etc. (Krąpiec et al. 2008, Scott et al. 1996, McAuliffe et al. 2006). Annual tree increments record both geomorphological processes of short-term, rapid course, as well as those occurring slowly. Techniques for testing the annual growth rings of trees are used for dating, assessment of intensity and spatial diversity of processes shaping the Earth's surface.

The aim of the present work is to assess the eccentricity of current annual increments in the trunks of spruce trees (Picea abies (L.) H. Karst) growing within the mountainous stream channel.

\section{Material and methods}

\subsection{Description of study area}

The research was carried out in the Silesian Beskidy Mts. (Polish Carpathians) in Istebna (Wisła Forest District, Bukowiec Forest Division) (Fig. 1). The $1.8 \mathrm{~km}^{2}$ basins of the Dupniański stream is the experimental catchment area, used for conducting research projects. A characteristic feature of the catchment is its diversity, both in terms of the terrain and geological structure, as well as the dynamics of water flow in the stream channel (Starzak et al. 2015). The catchment is located in a V-shaped valley with a height difference of $390 \mathrm{~m}$, with an average stream channel slope $11 \%$. Southern slopes are often shaped by landslides. According to the hydrogeological division (Kolago 1983), the research area is located in the Carpathian region, in the south-eastern macroregion. It features sandstone-shale flysch (fine-grained, medium- and coarse-grained Istebna sandstones and conglomerates).

In terms of tectonics, the Dupniański stream catchment is part of the Silesian Nappe unit, the nucleus of which consists of sedimentary rocks of the Istebna and Godula layers. Istebna layers were formed mainly as various siliciclastic rocks (Strzeboński 2003). Istebna sandstones, as various-grained deposits with a predominance of coarse sand, are composed of quartz, feldspar and mica cemented together with iron, quartz or clay. The soil is dominated by shallow medium and heavy clays, with a high content of dry soil particles.

The entire research area, which is characterized by significant differences in altitudes, belongs to the Carpathian climate division, moderately warm and moderately cold zones. The average annual air temperature is $6^{\circ} \mathrm{C}$, while the average annual rainfall ranges from 1100-1400 $\mathrm{mm}$. The snow cover lasts between 100 and 130 days a year, and its thickness reaches $60-100 \mathrm{~cm}$ (Obrębska-Starklowa et al. 1995). The average flow rate calculated for the years 1999-2001 is $33\left(1 \cdot \mathrm{s}^{-1}\right)$, specifically, $27\left(1 \cdot \mathrm{s}^{-1}\right)$ for the summer months and $40\left(1 \cdot \mathrm{s}^{-1}\right)$ for the winter months (Starzak 2006). The maximum observed flow rate is $432.53\left(1 \cdot \mathrm{s}^{-1}\right)$ and the minimum observed is $1.81\left(1 \cdot \mathrm{s}^{-1}\right)$. Unit 
runoff from the Dupniański stream catchment ranges from $15\left(1 \cdot \mathrm{s}^{-1}\right)$ to $23\left(1 \cdot \mathrm{s}^{-1}\right)$. The runoff coefficient from the catchment area ranges from 0.41 to 0.57 (1999-2001) and its value closely corresponds to runoff coefficient values for mountainous catchments of the Carpathian basin of the Vistula River (Urbanowicz 1989).

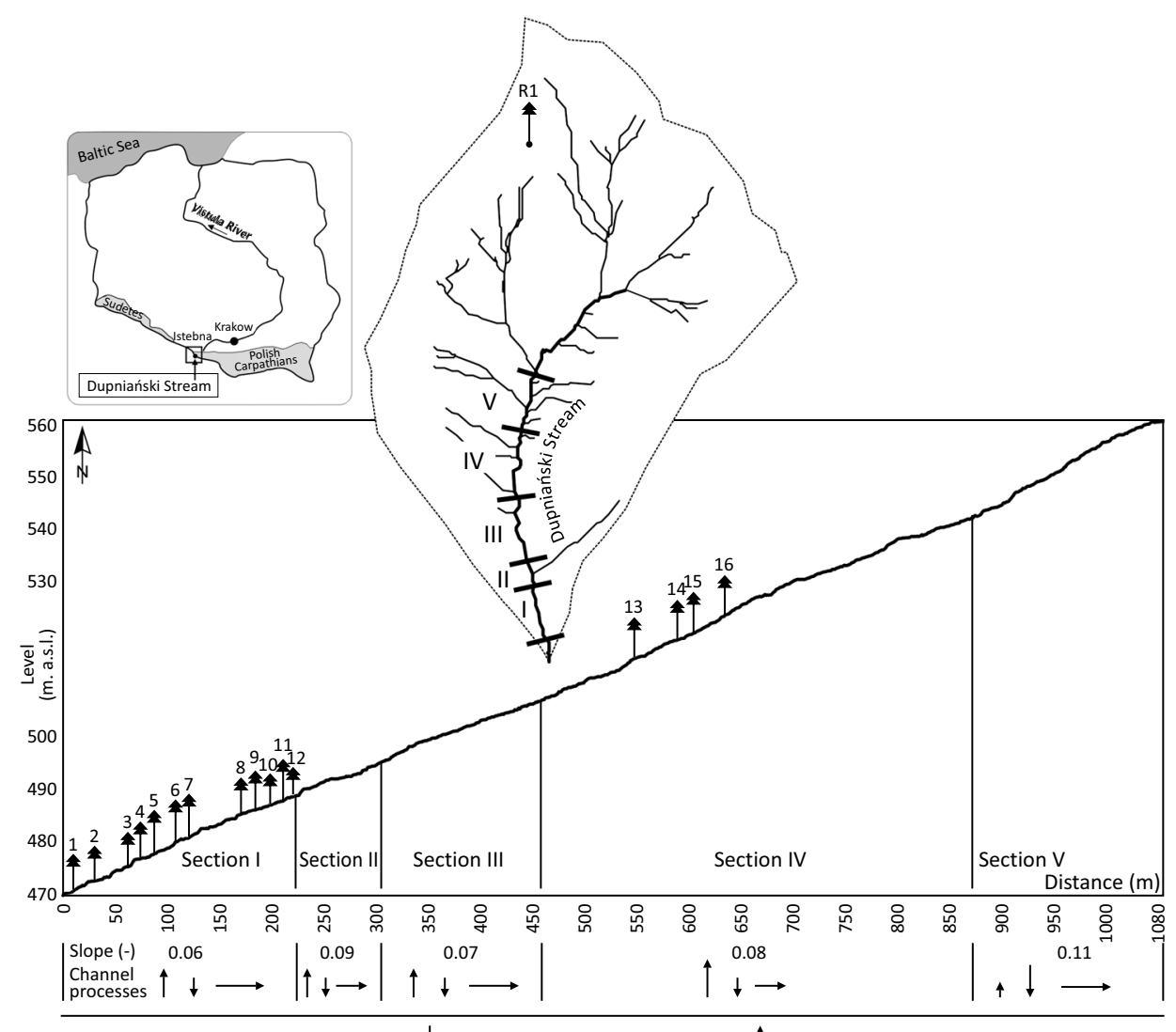

Channel processes: submerged erosion $\downarrow$, lateral erosion $\rightarrow$, accumulation $\uparrow$

Fig. 1. Study area - Dupniański stream catchment with the locations of Picea abies (L.) H. Karst spruce trees

The catchment of the Dupniański stream is characterized by high forest cover with a negligible share of arable land and non-forest land (Starzak et al. 2015). The main forest-forming species are: Norway spruce (Picea abies (L.) H. Karst), beech (Fagus sylvatica L.), fir (Abies alba Mill), and pine (Pinus sylvestris L.).

The Dupniański stream is a right-bank tributary of the Olza River, which belongs to the Odra River Basin. The stream channel is narrow and for the most part founded on rock outcrops. The width of the stream channel is from 0.8 to $3.5 \mathrm{~m}$ ( $1.7 \mathrm{~m}$ on average). Due to the geomorphological diversity of the longitudinal profile of the bed, 5 measuring sections (I-V) have been distinguished. 
Section I is located in the lowest part of the stream channel. Its length is $230 \mathrm{~m}$, and the slope is $60 \%$. The stream channel is straight, and typically cut out in bedrock, while at the bottom of the valley there are fragmentary sections of floodplain. The average width of the stream channel in the analysed section is $1.6 \mathrm{~m}$. Section II is the shortest of the five (86 $\mathrm{m}$ in length). The stream channel in this section is cut in thick-bedded Istebna sandstones, with thills and low thresholds on rock outcrops upon them, without alluvial material. The stream channel is straight, with an average width of $1.3 \mathrm{~m}$ and the slope of $90 \%$. At the bottom of the valley there are settled spills, built of sharpedged rock material, and overgrown with spruce trees. Section III has a length of $156 \mathrm{~m}$, the stream channel slope is $70 \%$, and the width is $2.0 \mathrm{~m}$ on average. There is a clear tendency to increase the winding of the stream. In the stream channel, at the convex banks, individual point bars were formed, mainly made of coarse-grained material: sharp-edged rubble and alluvial gravel, which indicates high-energy, but short transport of sediments. The stream channel on section IV is winding, with the length of 456 $\mathrm{m}$ and the slope of $80 \%$. The bottom of the stream channel is founded mainly on rock debris. At the convex banks there are small bars (1.6 m long, $1.0 \mathrm{~m}$ wide) with fresh gravel-sandy material. In sections where there are sandbars, the stream channel width increases to $3.0-3.5 \mathrm{~m}$, in sections without bars it amounts to $1.7 \mathrm{~m}$ on average. In the central part of the section, the route of the stream channel in the plan is forced by the presence of a landslide. Section $\mathrm{V}$ located in the upper part of the catchment. Its length is $177 \mathrm{~m}$ with the $110 \%$ o slope. The stream channel on this section is narrower (average width $1.4 \mathrm{~m}$ ) and deeper than in the other sections.

\subsection{Field and laboratory research}

As part of fieldwork, an inventory of trees along the stream channel was carried out on the selected research section. Only healthy trees with no visible mechanical damage, i.e. no signs of disease or hollows (Kojs et al. 2012) were selected. Samples from tree trunks were collected in two directions - downslope and upslope, at the height of diameter breast high (d.b.h.) (1.3 m) (Wistuba and Malik 2014, Wistuba et al. 2014). False or wedging growths occur in the trunks and roots, which can increase or decrease the duration of the high-energy event. Therefore, control of results is applied, which consists in comparison between the obtained sequence of annual growth and the one acquired from trees growing outside the zone of intensive impact of geomorphological processes (Malik and Wistuba 2012). In connection with the above, in addition to the collection of samples from spruces growing within the stream channel, samples were also collected from reference trees growing in the upper parts of the catchment in the flat area, i.e. outside the zone of intensive impact of geomorphological processes.

The sampling and preparation was conducted in accordance with the measurement methodology described in the paper by Zielski and Krąpiec (2019). Pressler tree ring drill with a diameter of $4.35 \mathrm{~mm}$ and a length of $40 \mathrm{~cm}$ was used. Samples collected in the field were properly secured, described and transported to the laboratory for further testing. 
Growth ring samples taken from the trees were prepared in accordance with the ECO strategy of dendrochronological research (Zielski and Krąpiec 2019). Scanning was performed on a scanner with a resolution of $1200 \mathrm{dpi}$. The measurements of annual growth ring widths were made using the CooRecorder software (Cybis Elektronik \& Data $\mathrm{AB}$ ), and subsequently synchronized using the CDendro application. Data for individual trees were compared and transformed into the eccentricity index of annual increments (Ei) using the following formulas (Wistuba et al. 2013):

$$
\begin{gathered}
E_{(x)}=U_{(x)}-D_{(x)} \\
E i_{(x)}=\frac{E_{(x)}}{D_{(x)}} \cdot 100(\%)>0 \\
E i_{(x)}=E_{(x)}(\mathrm{mm})=0 \\
E i_{(x)}=\frac{E_{(x)}}{U_{(x)}} \cdot 100(\%)<0
\end{gathered}
$$

where:

$E \quad$ - eccentricity of annual increment $(\mathrm{mm})$,

$\mathrm{Ei} \quad$ - eccentricity index of annual increment (\%),

$U$ - width of annual increment (tree ring width) on the upslope side of the trunk $(\mathrm{mm})$,

$D \quad$ - annual growth width on the downslope side of the trunk ( $\mathrm{mm})$,

$x \quad-$ year (annual increment),

$E_{(x)}>0$ : upslope eccentricity,

$E_{(x)}=0:$ no eccentricity,

$E_{(x)}<0$ : downslope eccentricity.

Simultaneously, measurements of the basic morphometric parameters of the stream channel cross-sections (width, depth) were carried out using a laser rangefinder and geodetic stakes. The position of tree trunks relative to the axis of the stream channel was also measured. In order to determine the characteristic grain diameter of the sediment $\left(d_{50 \%}\right)$, sediment samples were collected by the conventional method, belonging to the so-called surface methods (Książek et al. 2008). The samples were placed in plastic containers, labelled and transported to the laboratory for the testing of their granulometric composition (PN-EN 933-1: 1997).

\section{Results}

As a result of fieldwork conducted in 2015, 16 spruce trees were inventoried (Fig. 1). The paper presents the results of drilled samples taken from selected 4 spruce trees - namely, from those growing on the right and left embankments, and at different 
distances from the stream channel axis (Fig. 2), as well as from the reference spruce R1 (Fig. 3).

The first of the spruces in question is Spruce No. 4, $24 \mathrm{~m}$ high and $35 \mathrm{~cm}$ wide. It is spruce growing on the left bank of the stream channel in section I (Fig. 1). The width of the bottom of the stream is $1.8 \mathrm{~m}$, while the height of the embankment, measured from the bottom of the stream channel to the base of the trunk is $1.1 \mathrm{~m}$. The distance from the tree pith to the axis of the stream is $5.1 \mathrm{~m}$. The characteristic grain diameter of the sediment $\left(d_{50 \%}\right)$ is $24 \mathrm{~mm}$. Spruce No. 9 is a tree growing on the right embankment of the stream channel. Its height is $18 \mathrm{~m}$ and the diameter (d.b.h.) is $22 \mathrm{~cm}$. The width of the stream channel in this section does not exceed $1.6 \mathrm{~m}$, and the distance measured from the tree pith to the axis of the stream is $1.8 \mathrm{~m}$. Spruce No. 9 is located on the right side of the stream (section I). The height of the spruce is $18 \mathrm{~m}$, and the diameter (d.b.h.) is $22 \mathrm{~cm}$. The width of the bottom of the stream channel is $1.6 \mathrm{~m}$. The height of the shoulder from the bottom of the stream channel to the roots is $0.5 \mathrm{~m}$, and the width from the bank to the base of the trunk is $0.8 \mathrm{~m}$. The distance from the pith of the spruce to the axis of the stream is $1.8 \mathrm{~m}$. Leading from the stream axis on the left is a dirt road. Spruce No. 11 is a tree also growing in section I, on the right embankment of the stream channel. It has a height of $22 \mathrm{~m}$ and a diameter at breast height of $30 \mathrm{~cm}$. The width of the bottom of the stream channel is $1.6 \mathrm{~m}$. The pith of the spruce is located at a distance of $1.9 \mathrm{~m}$ from the axis of the stream channel. Fluvial sediments collected from the stream channel within the area of the occurrence of spruce trees No. 9 and 11 are mainly composed of gravel $\left(d_{50 \%} \geq 32 \mathrm{~mm}\right)$. The reference spruce $\mathrm{R} 1$ is a spruce tree growing in the highest part of the basin, in a flat area in a loose forest stand (0.4) (Szymański 1986). By analysing the developed charts (Fig. 2), it can be observed that the widths of annual increments of the tested spruces on the downslope and upslope sides are varied.

The sample obtained from Spruce No. 4 is characterized by the eccentricity index of current annual increments (Ei) greater than 0 (Fig. 2, Diagram 1), which indicates the dominant impact of the slope on the pith and its gradual deflection (1947-1957 and 1989-2012). However, in the years 1958-1987, the eccentricity index of current annual increments of Spruce No. $4(\mathrm{Ei})$ is greater than 0. Presumably, in the given time period, high-energy events in the stream channel resulted in mechanical stress and gradual deflection of the trunk. In the case of the sample obtained from Spruce No. 9, the eccentricity index of current annual increments $E i=0$ can be observed for most of the period, with the exception of the period from 1986 to $1988\left(E_{(x)}>0\right)$ and 1998-2003 $\left(E_{(x)}<0\right)$. Most likely, in the period preceding the year 1986, erosive phenomena on the slope (e.g. landslide) developed, while in 1998 a high intensity flood flow occurred in the stream channel, causing damage to the roots, or both the roots and the trunk of the spruce. Spruce No. 11 is growing in the highest part of section I. The eccentricity index of current annual increments in the period starting from 1988 is 0 , which indicates the absence of mechanical stress in the trunk, while (Ei) for the period 1954-1987 shows values less than 0 , which means a dominant impact of erosion processes occurring directly in the stream channel, resulting in tension and mechanical stress in the tree trunk. 
Spruce No. 4
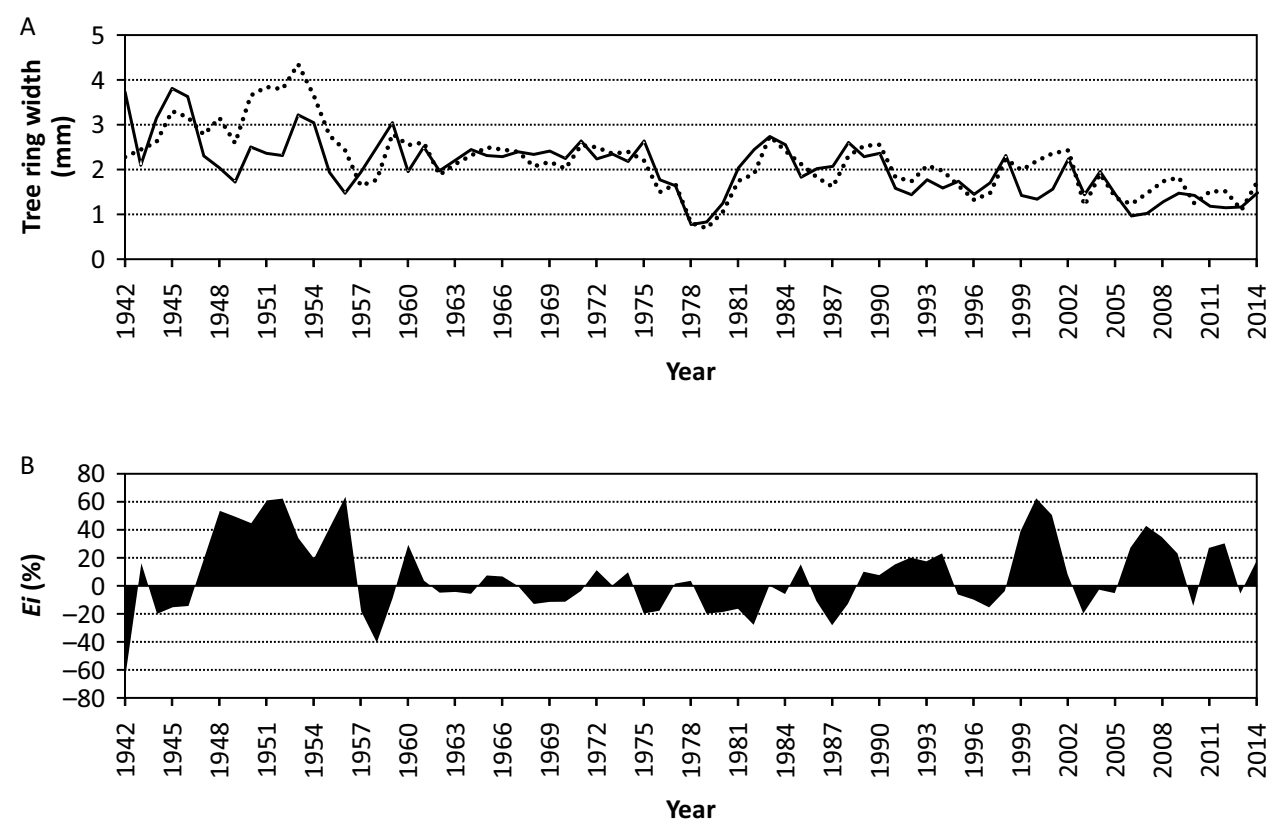

Spruce No. 9
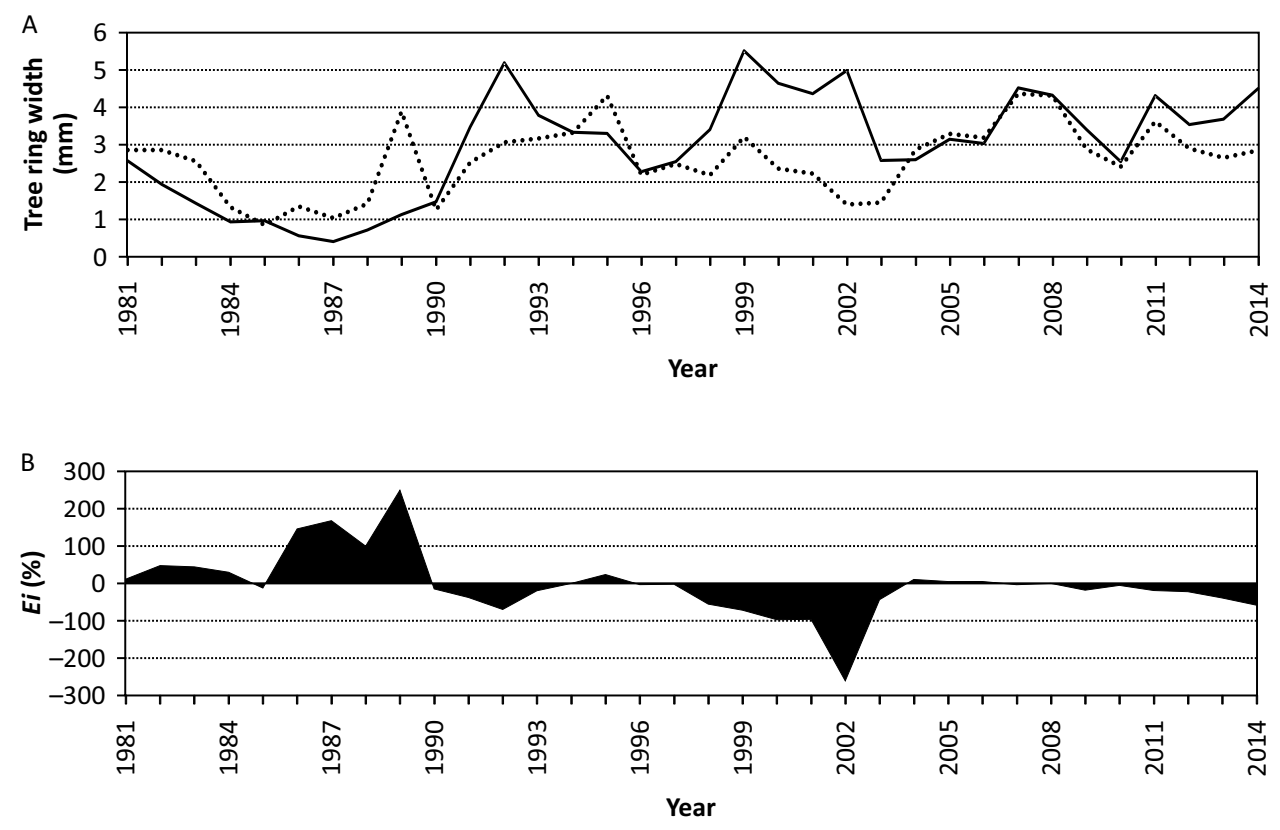

Fig. 2. Annual growth rings of the studied spruce trees: A - downslope tree ring width $(\mathrm{mm})$ (solid line) and upslope tree ring width ( $\mathrm{mm}$ ) (dotted line); B - eccentricity index (Ei) 
Spruce No. 11
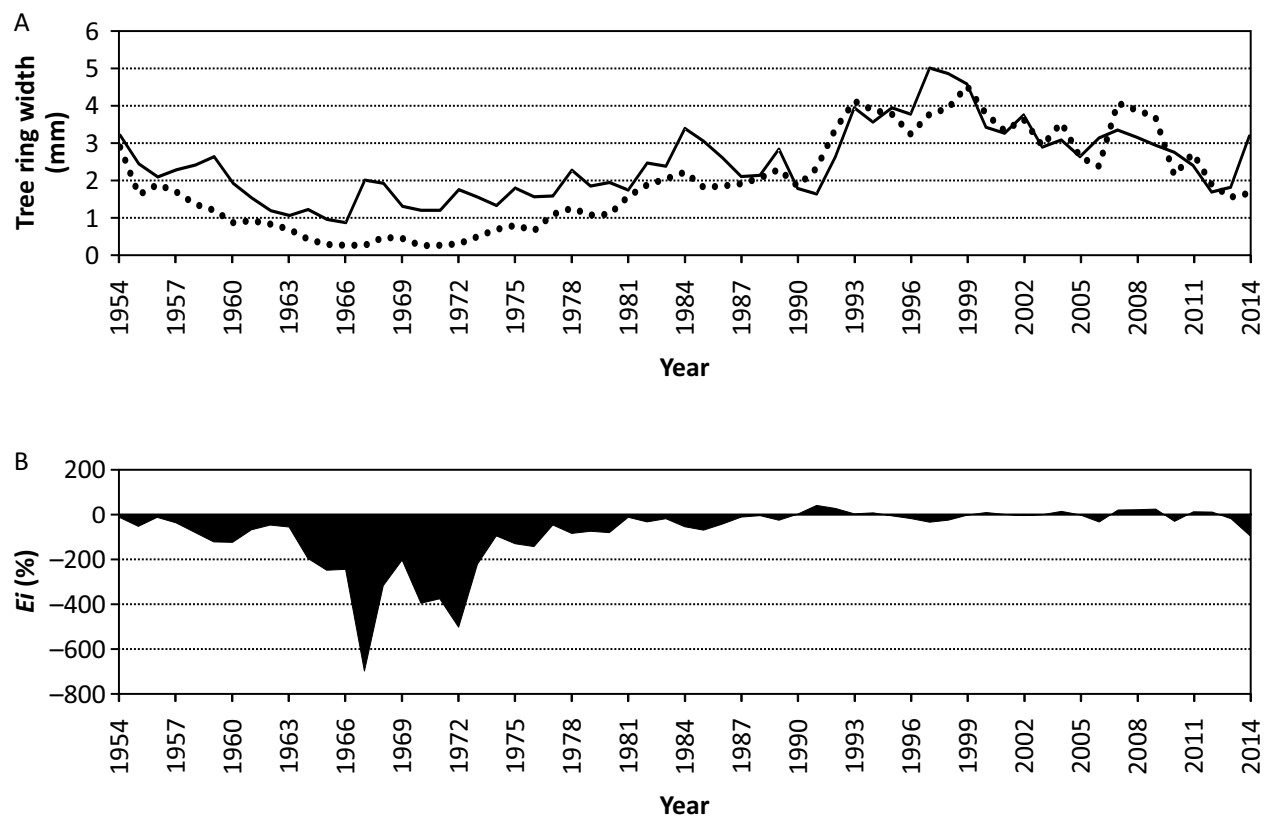

Fig. 2. cont.

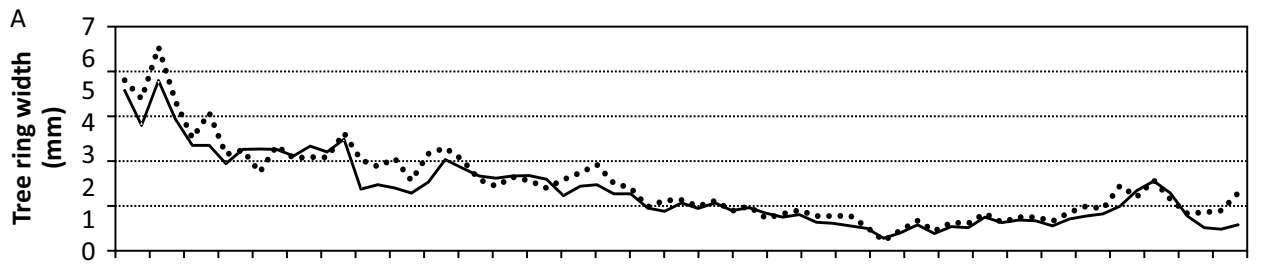

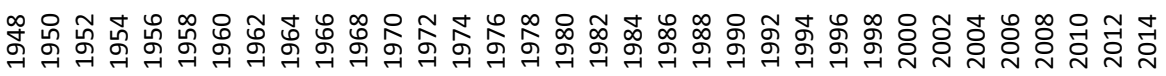
Year

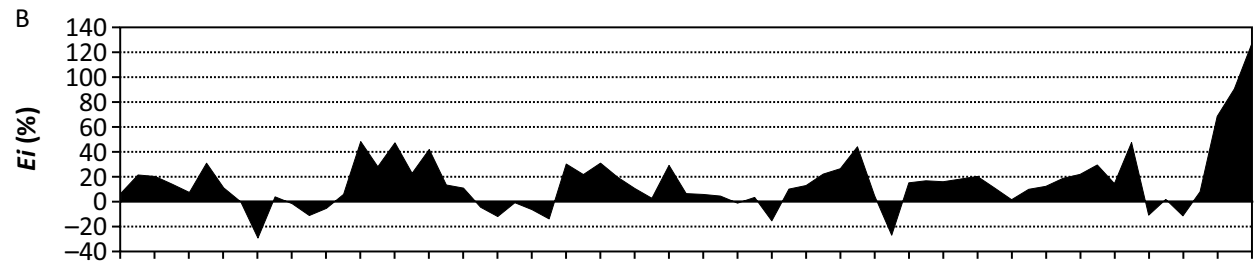

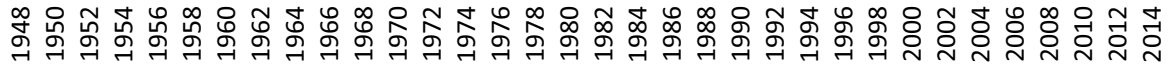
Year

Fig. 3. Reference spruce tree R1: A - tree ring width (mm) calculated based on the samples collected in the $(\mathrm{N}-\mathrm{S})$ direction: $\mathrm{N}$ (dotted line), S (solid line); B - eccentricity index (Ei) 


\section{Discussion}

The eccentric pith is located outside the geometrical centre of the trunk cross-section. The eccentric location of the pith can occur both in the trunk section and along its entire length (Kimbar 2012). It can occur on one side of the trunk, and often the location of the pith can be translocated to another part of the trunk or spirally along the trunk. There are many reasons for the occurrence of the eccentric pith, of which the most important is the presence of reactionary wood structures (e.g. compression wood in conifers), resulting in eccentric pith location (Barszcz 1995).

The differences in the width of current annual increments found on the upslope and downslope side of the trunks of the examined spruces, found as a result of the analysis of the results of laboratory work, may indicate a progressive eccentricity of annual increments as a result of erosive events occurring on the slope, as well as highenergy events occurring directly in the stream channel. The formation of the eccentric pith may occur as a result of the response of individual trees to ground movement as a result of slope instability (Wistuba et al. 2013). The deflection of tree trunks in the upslope direction testifies to the dominant impact of the erosion process that is taking place on the slope over the process of water erosion in the stream channel (Wistuba and Malik 2014). Eccentricity index values below 0 indicate the deviation of the trees from the vertical in the opposite direction to the slope. In the case of most of the examined annual growth rings, the eccentricity index values greater than 0 were recorded in the 1950s and 1980s. This evidences that erosion processes intensified on the slopes of the catchment area in the given period. An exception is the calculated eccentricity index of annual increments ( $E i$ ) for the sample taken from Spruce No. 11. In the case of this particular tree, the eccentricity index in the same time period is less than 0 , confirming the dominance of erosion processes in the stream channel over erosion processes on the slope (Wistuba and Malik 2014).

\section{Conclusions}

1. The highest values of eccentricity index of annual tree rings in the trunks for most of the examined spruce trees were recorded at the turn of the 1950s and 1960s as well as in the 1980s, which allows us to assume that high-energy events in the stream channel took place in the given period of time, resulting in significant damage to the roots and trunks of trees, combined with the intensification of erosion processes on the slope.

2. Eccentricity of annual tree rings in mountainous forested areas is an important issue from the point of view of forest management and protection of natural resources. The results of the conducted tests indicate the possibility of using the dendrochronological method in the study of erosive processes; however, it is necessary to conduct tests taking into account measurements of root injuries and hydrological characteristics of the catchment. 
3. Obtaining research results from samples of greater replication may contribute to the discussion on contemporary methods of examining erosion processes occurring in rivers and stream channels in forested mountainous catchments.

\section{References}

Barszcz A. 1995. Ocena jakości surowca drzewnego i zmienności wad drewna w rębnych drzewostanach świerkowych na terenie Beskidów. Zeszyty Naukowe AR w Krakowie, Rozprawy 199.

Butler D.R. 1987. Teaching general principles and applications of dendrogeomorphology. Journal of Geological Education, 35: 64-70.

Kimbar R. 2012. Wady drewna. Wydawnictwo Robert Kimbar.

Kojs P., Malik I., Wistuba M. 2012. Mechanizmy wzrostu ekscentrycznego i formowania drewna reakcyjnego w kontekście badań dendrochronologicznych - wprowadzenie do nowej hipotezy. Studia i Materiały CEPL w Rogowie, 14, 1(30): 147-156.

Kolago C. 1983. Nowa wersja podziału hydrogeologicznego Polski. Kwartalnik Geologiczny, 27, 2: 356-372.

Krąpiec M., Danek M., Gil. E., Kłusek M., Rączkowski W., Zabuski L. 2008. Monitoring dendrogeomorfologiczny osuwisk $w$ Beskidzie Niskim. Prace Komisji Paleogeografii Czwartorzędu PAU, 6: 173-184.

Lundstrom T., Stoffel M., Stockli V. 2008. Fresh-stem bending of fir and spruce. Tree Physiol., 28: 355-366.

Malik I., Wistuba M. 2012. Dendrochrnological methods for reconstructing mass movements - an example of landslide activity analysis using tree-ring eccentricity. Geochronometria, 39(3): 180-196.

McAuliffe J.R., Scuderi L.A., McFadden L.D. 2006. Tree-ring record of hillslope erozion and valley floor dynamics: Landscape responses to climate variation during the last 400 years in the Colorado Plateau, northeastern Arizona. Glob. Planet. Change, 50: 184-201.

Obrębska-Starklowa B., Hess M., Olecki Z., Trepińska J., Kowanetz L. 1995. Klimat. W: Karpaty Polskie. Przyroda, człowiek i jego działalność. Wydawnictwo UJ, Kraków, 31-47.

PN-EN 933-1:1997. Badania geometrycznych właściwości kruszyw: Oznaczanie składu ziarnowego. Metoda przesiewania. PKN, Warszawa.

Schweingruber F.H. 1996. Tree rings and environment. Dendroecology. Birmensdorf, Berne: Swiss Federal Institute for Forest, Snow and Landscape Research, WSL/FNP, Paul Haupt.

Scott M.L., Friedman J.M., Auble G.T. 1996. Fluvial process and the establishment of bottomland trees. Geomorphology, 14: 327-339.

Shroder J.F., Jr., Butler D.J. 1987. Tree-ring analysis in earth sciences. In: Proceedings of the International Symposium on Ecological Aspects of Tree-ring Analysis. Red. G.C. Jacoby, J.W. Hornbeck. Lamont-Doherty Geological Observatory and U.S Department of Agriculture, 186-212.

Starzak R. 2006. Dynamika zapasu wody w glebach wybranych drzewostanów świerkowych Beskidu Śląskiego. Rozprawa doktorska. Akademia Rolnicza w Krakowie, maszynopis.

Starzak R., Kucza J., Suliński J. 2015. Dynamika zapasu wody w glebach pod wybranymi drzewostanami świerkowymi Beskidu Śląskiego w latach 1999-2004. W: Ekologiczne i hodowlane uwarunkowania przebudowy drzewostanów świerkowych w Beskidzie Śląskim i Beskidzie Żywieckim. Red. S. Małek, Wydawnictwo UR, Kraków.

Stoffel M., Corona C. 2014. Dendroecological Dating of Geomorphic Disturbance in Trees. Tree-Ring Research, 70(1): 3-20. 
Strzeboński P. 2003. Sedymentacja warstw istebniańskich (górny senon-paleocen) zachodniej części serii ślaskiej Karpat. Sprawozdanie z posiedzenia Kom. Nauk Geol. PAN, XLVII/2.

Szymański S. 1986. Ekologiczne podstawy hodowli lasu. PWRiL, Warszawa.

Urbanowicz A. 1989. Bilans wodny małych zlewni górskich o różnym rolniczo-leśnym zagospodarowaniu. Problemy Zagospodarowania Ziem Górskich, 29: 115-133.

Wistuba M., Malik I. 2014. Sprzężenie stok-koryto zapisane w przyrostach rocznych drzew i w rzeźbie terenu gór średnich (Karpaty Zachodnie i Sudety Wschodnie, Republika Czeska). W: Krajobrazy młodoglacjalne, ich morfogeneza, teraźniejszość, przyszłość. Red. P. Molewski, W. Juśkiewicz. Materiały X Zjazdu Geomorfologów Polskich, Uniwersytet Mikołaja Kopernika w Toruniu, Wydział Nauk o Ziemi, Toruń: 122-123.

Wistuba M., Malik I., Gärtner H., Kojs P., Owczarek P. 2013. Application of eccentric growth of trees as a tool for landslide analyses: The example of Picea abies Karst. in the Carpathian and Sudeten Mountains (Central Europe). Catena, 111: 41-55.

Wojciechowski W., Kęsy J., Kopcewicz J. 2013. Mechanizmy powstawania drewna u drzew leśnych. Zarządzanie ochroną przyrody w lasach, VII, 205-232.

Zielski A., Krąpiec M. 2019. Dendrochronologia. Wydawnictwo Naukowe PWN, Warszawa.

Acknowledgements and financing sources

This work was supported by the National Centre for Research and Development and the Polish-Norwegian Research Fund (Grant No. 209947/52/2013-2016).

\section{EKSCENTRYCZNOŚĆ PRZYROSTÓW ROCZNYCH W PNIACH ŚWIERKÓW (PICEA ABIES (L.) H. KARST) ROSNĄCYCH WZDŁUŻ KORYTA POTOKU W MAŁEJ ZLEWNI GÓRSKIEJ W POLSKICH KARPATACH}

\section{STRESZCZENIE}

Występujące w korytach rzek i potoków górskich wezbrania, połączone z transportem materiału skalnego, powodują erozyjne podcinanie skarp i uszkodzenia odsłoniętych systemów korzeniowych drzew rosnących na skarpach. Konsekwencją zdarzeń wysokoenergetycznych zachodzących w korycie cieku jest powstawanie stresu mechanicznego w postaci naprężeń wewnątrz pni drzew, skutkujących zmianą wzoru funkcjonowania kambium i odchylaniem się rdzenia pnia. W pracy przyjęto hipotezę, że nie tylko gwałtowne zjawiska osuwiskowe, lecz także działalność erozyjna potoku może powodować odchylanie drzew od pionu, co skutkuje występowaniem dekoncentryczności w przyrostach drewna drzew rosnących w sąsiedztwie koryta cieku wodnego. Dzięki tej cesze drzew można ponadto określić precyzyjnie czas występowania w przeszłości zjawisk erozyjnych o dużej intensywności, jak również wskazywać miejsca wzdłuż biegu cieku wodnego szczególnie narażone na te procesy, co podkreśla utylitarny aspekt pracy. Celem pracy jest ocena przebiegu dekoncentryczności słojów rocznych w pniach świer- 
ków (Picea abies (L.) H. Karst) rosnących wzdłuż koryta potoku w małej leśnej zlewni górskiej. Przedmiotem badań są szerokości słojów drewna tworzonych przez świerki po dwóch stronach pnia, jako forma odpowiedzi na działalność erozyjną potoku. W ramach prac terenowych pobrane zostały odwierty z użyciem świdra Presslera. Przyrosty roczne pni świerków określono z użyciem programu CooRecorder, a uzyskane wyniki poddano korekcie w programie CDendro. Najwyższe wartości indeksu dekoncentryczności przyrostów rocznych $\mathrm{w}$ badanych świerkach odnotowano w latach 60 . i 80 . ubiegłego wieku. Przyczyną powstania naprężeń wewnątrz pni badanych drzew są zarówno naturalne procesy erozyjne zachodzące na stokach w zlewni, jak i zdarzenia wysokoenergetyczne zachodzące w korycie cieku. Ocena przebiegu dekoncentryczności przyrostów rocznych, w połączeniu z badaniami geomorfologicznymi i hydrologicznymi, może znaleźć zastosowanie w pracach ujmujących problematykę dynamiki procesów erozyjnych zachodzących w leśnych zlewniach górskich.

\section{SŁOWA KLUCZOWE}

Polskie Karpaty • zlewnia leśna • potok • świerk pospolity • przyrosty roczne • indeks dekoncentryczności 